\title{
Electoral Politics, Multi-partism and the Quest for Political Community in Ethiopia
}

\author{
Solomon Mebrie*
}

\begin{abstract}
Following the coming into power of the EPRDF (Ethiopian People's Revolutionary Democratic Front) in 1991, several political organizations took part in the political process in Ethiopia that promised a multi-party system. Although general elections in which several political organizations took part were held in 1995, the May 2005 elections provided an opportunity for the people to participate in the elections en masse. This paper argues that while the EPRDF indulged in the rhetoric of multi-party politics before the 2005 election, its crackdown in the aftermath of the same, its claims of total victory in 2010 and 2015 elections, and the politics of antagonism it has been persistently pursuing exposed the regime's lack of commitment in multi-party elections as an important aspect of democratic politics. Secondly while the protests of 2014-2017 and the subsequent initiatives on the part of the government since have rekindled hope for democratic engagement, uncertainties remain. By using state-society relations as framework of analyses and reviewing secondary sources - books, articles, reports and web sources - this article makes a critical reflection on multi-party political rhetoric, the consequences of political control and repression, the significance of the concept of political community for political transformation in general and the conduct of genuine multi-party elections in the country in particular in the future.
\end{abstract}

Keywords: multi-partism, electoral politics, political antagonism, political community in Ethiopia

DOI: https://dx.doi.org/10.4314/ejossah.v14i2.4

\footnotetext{
*Associate Professor, Department of Political Science and International Relations, Addis Ababa University, Email: sgofie@yahoo.co.uk, Tel: +251911068498, P.O. box: 1176/ Addis Ababa
}

This work is licensed to the publisher under the Creative Commons Attribution-NonCommercialNoDerivs License. 


\section{Introduction}

In 1991 the Tigray People Liberation Front (TPLF) led Ethiopian People's Revolutionary Democratic Front (EPRDF) with its allies, toppled the militarysocialist regime commonly known as the Derg (1974-1991) and went onto configuring its relationships with the various categories of the Ethiopian people. One of the major political developments in Ethiopia since then was the introduction of multi-party political dispensations, which was generally new in Ethiopia at that time. There was no scope for multi-party elections during the monarchical period in Ethiopia (Arriola, 2005). A nominal one-party election was held under the Derg's Workers Party of Ethiopia (WPE) for the formation of the Biherawi Shengo (national assembly or council) in 1987.

In the post 1991 period, the EPRDF regime, with encouragement of its external allies arguably helped the introduction of multiparty politics. The EPRDF invited several political organizations calling themselves 'fronts', 'parties', 'forces' or 'movements', etc., to participate in what was called the Transitional National Conference convened in Addis Ababa in July 1991. The Conference created the 87-seat Council of Representatives that served as a 'parliament' during the transitional period (1991-1995). About 30 political groups or organizations took part in the Conference (Vaughan, 1994). The EPRDF-led Transitional Government of Ethiopia (TGE) was established with representatives from the EPRDF and other political groups such as the Oromo Liberation Front (OLF) at that time. The Transitional Period Charter served as a framework for a nominal election, to the exclusion of groups such as the OLF, was held in 1992 for the formation of "regional assemblies" (Lyons, 2010).

During the transitional period, old and newly formed political organizations wanted to take advantage of the democratization dispensations that seemed to promise multi-party electoral competition. Since then, political organizations continued to emerge or merge or in some cases disappear from the Ethiopian political scene. Another election, for the formation of the "constituent assembly" was held in 1994, allowing the EPRDF to maintain absolute majority of the assembly. After adopting the 1995 constitution, different political organizations participated in what was considered the 'first general elections' held in May 1995. These elections, while they did not significantly contribute to the genuine democratization of the country, they may have helped in the legitimization of the TPLF dominated EPRDF as the sole arbiter in the post 1991 political order, in the run up to the official proclamation of the Federal Democratic Republic of Ethiopia (FDRE). In these elections, the EPRDF and its affiliates claimed to have won in absolute majority dominating the political landscape (Lyons, 2010). 
The second general elections were held in May 2000. The EPRDF allowed political organizations ('opposition') outside state power to take part in the elections. Candidates of 'opposition' groups were able to participate and compete in about half of the country's electoral districts in these elections. Financial capacity, harassment and intimidation by state functionaries especially at the local administration levels were cited as the major factors which impeded the political organizations and the candidates they fielded, in effectively competing with the EPRDF and its affiliates. Consequently, the EPRDF and its affiliates took the overwhelming majority of seats in the House of Peoples' Representatives (Pausewang \& Tronvoll, 2000).

The analyses in this paper focus on the rhetoric of multiparty elections in Ethiopia with a focus on the post 2005 period, raising other major issues, the EPRDF's mode of political mobilization and strategies of control of the population, that have not been conducive for the institutionalization of credible party system or multi-party politics and the conduct of genuine elections. It touches on popular protests (2014-2017), political reform initiative since 2018, the key challenges in the present context, and presents reflections on the significance of the concept of political community for the future transformation of political conditions in the country. In the next section the article discusses conceptual issues relating to multi-party politics, electoral politics or democracy, political community and state-society relations. The third part makes a critical assessment of the last three general elections $(2005,2010,2015)$ in Ethiopia, as these form the "corpus" in the experience and rhetoric of multiparty elections for about a quarter of a century. The fourth section makes a critical analysis of the strategies of the EPRDF, its ambitions and practices of control of the political, economic and social life of the population, the nature of its relations with political organizations outside state power and the society more broadly, and the failure of the former in learning lessons for the genuine democratization and institutionalization of multi-partypolitics and the conduct of free and fair elections and beyond. The discussion then proceeds to the key challenges currently, following the reform initiatives since early 2018, and concludes with reflections on the quest for a viable political community for political transformation and meaningful political processes in which genuine elections will be held and challenging political issues may be resolved in Ethiopia in the future.

\section{Conceptual Clarifications}

The discussion in this part focuses on the clarification of major conceptual themes raised in this paper. These are multi-party elections or democracy, political 
community and state-society relations. To begin with, party system in general, and multi-party in particular imply that there exist multiple and diverse interests in the society- the people constituting modern political communities, giving rise to or the formation of political organizations the primary roles of which are to identify, articulate, and aggregate the interests of groups and individual members of the society (Friedrich Ebert Stiftung, 2010). These political organizations are formally called parties, and the notion of multi-party refers to the situation in which more than two parties function or compete in elections. In democratic political systems parties provide the platform to debate and articulate the demands and the interests of members of the society and develop them into political programs. A democratic system or democracy as Makinda suggests, is "a way of government firmly rooted in the belief that people in any society should be free to determine their own political, economic, social, and cultural systems" (1996, p. 557). Similarly, a prominent scholar on Democracy, Dahl, maintains that,

We interpret it as consisting of the rule by the people, or rather demos with a government of the state that is responsive and accountable to the demos, a sovereign authority that decides important political matters either directly in popular assemblies or indirectly through its representatives, chosen by lot or, in modern democracies, by means of elections. Viewing democracy from the second point of view, we interpret it as providing an extensive body of rights. These are of at least two kinds. One consists of rights, freedoms and opportunities that are essential to popular control and the functioning of the democratic institutions themselves, such as freedom of speech and assembly (2001, p. 20).

In a democratic system, people periodically and regularly elect their leaders and representatives through the mechanism of free, fair and transparent elections. Elections play paramount role in providing opportunities for choosing the representatives of the people democratically, and serve as mechanism for peaceful transfer of power or change of government. Democracy understood in this sense, and when translated into practice, provides the necessary conditions in which political organizations or parties exist and compete for the votes of members of the political community or citizens, as basis of holding office for a limited period of time or term. It is a political order in which people (citizens) have their say in matters affecting them, actively participate and work to achieve and maintain control of the political system, thereby limiting the power of the 96 
government they themselves make (Menocal, 2014). In a democratic political system, citizens have equal say in deciding on matters that affect them and that "opposition to currently prevailing policies is always legitimate" (Shapiro, 2001, p. 211).

In discussing multi-party politics and elections in general, what is of primary importance is not the nominal or formal existence of several political organizations, and the periodic conduct of elections. The mere existence of several political organizations may provide a system with a nominal presence of 'party system' while it does not lend it credibility. Genuine multi-party elections take place within a democratic political system. Put differently, a democratic order in which political parties compete for the votes of citizens exists in practice when people are at liberty to express their ideas without fear, i.e., when freedom of expression, freedom of speech, assembly and association are realized, and the actual exercise of these freedoms could be served best in the presence of democratic institutions (Dahl, 1989). Empirical studies show the widening gap between the conceptual meaning of democracy as explained above and the divergent practices and controversies surrounding the various perspectives on multi-party politics or elections and the divergent practices in the present context. Nothing explains the divergences than the emergence of terms such as "multi-party democracy" or "electoral democracy" (Beer, 2001; Rothstein, 2009), "electoral authoritarianism" (Kou \& Kao, 2011; Shirah, 2016), "hybrid regimes" (Boggards, 2009), "dominant party" system (Arian \& Samuel, 1974; Boggards, 2004) in the literature on multi-party politics or elections. The implication here is that "multiparty democracy" or "electoral democracy" does mean different things in different contexts.

Here, the writer employed the term mutli-partism to indicate the circumstances in which the EPRDF regime and its proponents indulged in the rhetoric of multi-party politics that presented a less than genuine political process, presumably aimed at the democratization in Ethiopia since early 1990s. Multipartism here in this article is understood as rhetoric of multi-party politics and elections as different from meaningful or credible electoral discourses and practices. It refers to pretentious pronouncements of politicians engaging in various practices which allow political organizations to take part in elections that are not genuine or elections without integrity. The term electoral integrity gained considerable importance and being frequently cited following experiences of electoral fraud, malpractices or serious irregularities. The notion of electoral integrity maintains that, for an election to be meaningful, it has to fulfill the standards of democratic elections. This means, in short, elections fulfilling the 
criteria of free and fair elections (Norris, 2015). With regard to this, the Universal Declaration of Human Rights (Art. 21-3) underlines that "the will of the people shall be the basis of the authority of government expressed through periodic and genuine elections which shall be by universal and equal suffrage and shall be held by secret vote or by equivalent free voting procedures." Article 25 of the International Covenant for Civil and Political Rights lists elements of free and fair elections- periodic elections at regular intervals, universal suffrage, one person one vote, the right to elect and to be elected, etc. It also mentions the term "genuine" elections, which is frequently used in this paper. Genuine elections do not exist in a vacuum. Genuine elections take place in conditions where the political rule of the game allows the exercise of the free will of the people-citizen-members of political community. This is important because elections in many parts of the world have become pretentious (Blaydes, 2006) and it's baffling to see millions of people queuing on election days without the readiness on the part of those in command of state power to allow the conduct of free and fair election. It is the rhetoric and the 'democratic pretensions' (Pausewang et al., 2002) described in this paper as multi-partism which captures the experience in Ethiopia.

Another key concept in this paper is political community. Political community is a long standing concept in political theory, which does not seem to be given adequate attention in political analyses of recent times, however. At the most general level it denotes the notion that people in what are conventionally called states constitute a community the essence of which is political--hence political community--of shared political ideals, common destiny, and for the common good. In normative political theory, while the concept of political community may be closer to the concept of polity, it is different from the concept of the state dominating understandings in political and social sciences in the modern context (Linklater, 1998). While the state is an overarching institutional structure (Kalpokas, 2016), political community is the constitutive element, i.e. the body politic. Here what is important is not the fact of being in a state; it is rather the unity or solidarity - the will and the capacity of the people to stand together the bond (Baker \& Bartelson, 2009) which defines a political community and its viability. This means that the idea of political community transcends the ideas of state and nation (Husserl, 1939). Beyond formal belonging, political community presupposes the existence of meaningful sense of belonging and citizenship, such as life of dignity, the right to subsistence and security, freedom of association and expression, equality, the rule of law and justice. The understanding that the will and the capacity of the people to stand together under the rule of law, also serving as the guardian of the same, are critical elements in the conception of political 
community. While there could be various ways of explaining the attributes of a political community, I would argue that dignity, freedom, solidarity, justice and the rule of law are among the major defining features or values of viable political communities. Therefore, for the purpose of the analyses in this paper, political community could be understood as a union of free people that have chosen to live under a political order for the purpose of their common economic, political and social wellbeing. Political community (ies), whose members are endowed with human dignity, freedom and solidarity, and sense of meaningful citizenship serves as the foundation of a well functioning state, legitimate government, and ultimately a political order in which the business of politics, including genuine elections, can be conducted in orderly and predictable manner.

Finally, state-society relations is another concept briefly explained in this section of the paper. 'State-Society' is analytical framework which denotes the 'relational' significance of state and society as higher categories of human association. The various aspects or elements constituting the categories of state and society interact in multiple forms. At the general level, the term 'state-society' denotes relations that are antagonistic or complementary (Solomon, 2007). The writer argues that state-society relations in the post-Derg Ethiopia have been antagonistic. This can be explained by the fact that the interests of those at the helm of state power in the post 1991 period in Ethiopia diverged from the needs and aspirations of the various categories of the society, which among other consequences resulted in fear, fragmentation, and distrust within the population during this period (Solomon, 2007). Electoral politics, multi-partism and political community are employed here as points of reference being examined in statesociety relations of antagonisms characteristics of the situation in Ethiopia during the past decades. It could therefore be argued that antagonisms best expressed by the political rhetoric and practices of the repressive TPLF-EPRDF regime that opted to dominate or even aspired for the total control of the society (Aregawi, 2008) diminished the chances of having genuine multi-party election.

Beyond making multi-party politics a mockery, the more than a quarter of a century of EPRDF rule contributed to fear, fragmentation and disunity widely felt within the Ethiopian body politic in the post 1991 period. The predominant approach used in writing this report is document analysis. Several works relating to contemporary political developments in Ethiopia including electoral politics have been explored. A lot has been said about successive elections in Ethiopia. However, there is a need to review and provide a critical assessment about elections and multi-party political dispensations in Ethiopia in a manner capturing the nature of state-society relations during EPRDF's rule, the major issues 
surrounding the conduct of general elections in the country so far, as well as by reflecting on the current dynamics and the challenges ahead. In doing so, books, journal articles, research reports and web resources have been explored. The next section discusses the rhetoric and practices of multi-party politics in Ethiopia with a focus on the general elections during 2005-2015 period.

\section{Multi-partism and Electoral Politics in Ethiopia (2005-2015)}

The May 2005 Elections were the 'third general elections' which observers of contemporary political developments in Ethiopia have considered the most significant electoral event occurred in the country to date (Abbink, 2006). These elections, as Arriola observed,

marked a significant evolution in the Ethiopia's political development, as the country transitioned from de facto single party system to a multiparty system. In a country with no history of democratic competition or peaceful alteration in power, it is no small feat that nearly a third of districts, if election results are accepted as they are, opted for the opposition over the EPRDF (2003, p. 137).

First and foremost, the May 2005 elections appeared to have given a more credible opportunity to the people of the country to participate in the elections in record numbers. Perhaps for this first time in the country's history the Ethiopian people may have voted hoping that they may be able to change the government through a ballot box. Secondly, the May 2005 elections could be considered as one of the rare instances in which poorly organized political organizations ${ }^{1}$ outside state power mounted a considerable electoral challenge against the incumbent - the EPRDF that was bolstered by years of control of state power, empowered by access to state resources and manipulation of the political environment. Thirdly, the political context in the run up to the 2005 elections was comparably permissive, thereby allowing political organizations or the opponents of the ruling

\footnotetext{
${ }^{1}$ A few political organizations which posed formidable challenge against the incumbent EPRDF during the 2005 elections were organized in just a short period of time-in a few months before the elections. The Coalition for Unity and Democracy (CUD) and United Ethiopian Democratic Forces (UEDF) were cases in point, where these organizations overwhelmed by the growing number of supporters were not able to convert the support into a coherent party membership, organization and discipline.
} 
EPRDF to campaign relatively freely and openly. Consequently, unlike the previous elections, several political organizations campaigned actively in almost all parts of the country (Lyons, 2005).

In general, the May 2005 elections took place in the context where the EPRDF regime allowed a relatively permissive political environment in the runup-to the elections. During the campaigns, live televised debates were held allowing the political organizations to present their positions and to debate publicly. The land issue, group rights vis-à-vis individual rights, poverty and economic development, governance, rule of law, foreign relations were the topics addressed during the debates. However much of the theatrics were conducted in the form of the choice between revolutionary democracy, which the EPRDF claimed to have firmly stood for, and 'liberal democracy' arguably advocated by political groups such as the Coalition for Unity and Democracy (CUD) at that time. Moreover, the proceedings of the debates were indicative of the lack of agreement between the ruling EPRDF and its opponents on critical issues that were supposed to form the 'organizing principles' of the Ethiopian body politic and its institutions since the 1990s (Abbink, 2006).

On 15 May 2005 the elections took place where the turnout was estimated between $80 \%-90 \%$ of those registered to vote. The election day was recognized to have been largely peaceful. On 16 May 2005, the EPRDF announced that it won the general elections, but confirmed that it lost to the CUD all but one of the seats of the Addis Ababa City Council. Major disagreements ensued after the opposition groupings also started to claim victory countrywide. As events unfolded, it announced the ban on public demonstration. On 08 June 2005 street demonstrations took place in Addis Ababa and state security forces killed several people. Widespread protests and deaths and detentions were reported in the Oromia and Amhara regions in particular (Carter Center, 2009).

The May 2005 elections also witnessed the involvement of a relatively large number of local and international election observers. The latter category consists of the African Union Election Observation Mission (AU), the Carter Center, the European Union Election Observation Mission (EU-EOM) and the Arab League. These observers, however, came up with divergent views in their reports. The AU Observers Mission claimed it confirmed that the elections were fair. The Carter Center on its part claimed that while there were irregularities, it did not reject the results. The EU-EOM's view, however, differed from the two significantly. As Abbink commented on the position of the EU-EOM, 
Praise was given for the preliminary phase, the relatively free debate and campaigning, the technical preparations, and the voting process, but it was critical about the voting day practices and the selective intimidation of voters and opposition candidates. EU observers did not see the voting process in the large majority of the rural constituencies. They nevertheless did a commendable job, showing that the EU took its role of observer seriously (2006, p.12).

The EPRDF government on its part responded to the reports, especially to reports of the EU mission in a hostile manner. After the official result was announced, the then Prime Minster of Ethiopia, Meles Zenawi issued a series of statements published in the state owned English daily, the Ethiopian Herald of 2931 August 2005 editions. This was in response to the EU preliminary report, to ridicule the assertions of the Head of the Mission, Ms. Ana Gomes of the European Parliament. Overall what was considered a historic election turned out to be a tragic event, and it did undoubtedly left its mark on the processes and the outcomes of 2010 and 2015 elections. It sent a shock wave within the rank and file of the EPRDF regime looking at the figures, and raising questions as to whether they were ready to concede in an event of electoral defeat or a considerable lose in its control over the rugged Ethiopian political landscape. Consequently, the period between the 2005 and the 2010 elections was characterized by a series of measures the EPRDF took to recover from the shock of 2005 elections, the dramatic weakening of political organizations generally termed as 'opposition', (Yemane, 2010) and the repression unleashed against protestors, mainly students in Addis Ababa and Oromia regions of the country. The repressive measures forced the resignation of many people from actively participating in the political life of the country. Worse still, the EPRDF and its members or supporters openly went onto engage in practices which undermined the integrity of any future elections. Consequently, in the immediate aftermath of the May 2005 elections the EPRDF did not waste time to prepare, ensure and "win" all the recall elections while this period reached its lowest for the 'opposition' groupings beset by intimidation, imprisonment of their officials, desertion of members, internal rivalries and creation of splinter groups, often perceived as a ploy by the regime to destroy or weaken its opponents (Pettersen \& Salvesen, 2006).

One of the major strategies of control of the population, the institutions and the economic resources by the EPRDF and the so called partner organizations (referring to EPRDF affiliate political organizations in control of the regions of 
Afar, Benshangul-Gumuz,Ogaden, and Gambella) had been blurring the distinction between these political organization in state power and the public/government institutions (Sarah, 2011). Such practices have been consequential and responsible for the lack of credibility and integrity of the institutions and the processes during previous as well as subsequent elections. While the civil service, public institutions and public resources were used by the EPRDF in the run-up to previous elections (Brechenmacher, 2017), the crisis after 2005 elections led the regime to openly resort to favoritism to achieve total control of the institutions and the use of public resources for purposes of self-aggrandizement of the 'officials' and network of beneficiaries. It turned to recruiting new members en masse. Patron-client relations that spread like a wild fire within state institutions became part of the strategy of the EPRDF and its allies to remain in control by satisfying the interests of its dependent groups of beneficiaries they created. As 'opposition' political organizations were crumbling due to the repression and internal bickering, the EPRDF and its affiliate or 'partner' organizations have often been accused of using state structures and resources to help organize support bases. These include women and youth leagues and associations, all of which have been directly linked to local government structures such as the Woreda and the Kebele, the lower tiers of government in Ethiopia. The EPRDF and its 'partner' organizations offered job opportunities and economic benefits, while at the same time their practices went to the extent of depriving the economic means of subsistence of individuals and groups considered members or supporters of political organizations outside state power, the 'opposition'.

On the part of political organizations of the 'opposition', the period after the 2005 elections was characterized by the weakening of their capacity. Internal rivalries, which were often perceived to have been instigated by the EPRDF, were by far the most significant feature in the dramatic disintegration of some of the major opponents of the EPRDF in the immediate aftermath of the elections. Beset by the rivalries, the larger organizations while protesting against the actions of the EPRDF were clearly unable to attend to the business of politics in rapidly changing

\footnotetext{
${ }^{2}$ There were practices whereby job applicants attach their EPRDF membership Identity Card with job application, circumstances in which business groups win government contracts without a formal bid process, to the detriment of real or perceived opponents. The former Oromo People's Congress now Oromo Federalist Congress over the years reported cases in which its members and supporters were dispossessed. And ironically nothing explains this situation than the experience of one high ranking official of the organization, who was denied the continuation of employment, academic promotion, and was evicted from a government rental house!
} 
circumstances (Smith, 2007). In this regard, the crisis within the CUD leadership in the immediate aftermath of the 2005 in particular served as a showcase of the precarious state of the organizations in opposition to EPRDF. The drama unfolded in such a way that the CUD that amassed considerable popular support in a very short period of time just before the 2005 elections was being threatened with disintegration, despite the appeals on the part of its supporters to remain united. The divisions within the CUD deepened while most of its prominent figures were in detention during the immediate post electoral period (Amnesty International, 2006). Although the crisis within the CUD as the major coalition that gained considerable support was at the center of attention after the 2005 elections, similar problems did happen within the UEDF as the second largest coalition in opposition. The crisis within the ONC, a member of UEDF coalition, for instance was no less dramatic. Its office was squandered and the organization disintegrated following the emergence of splinter group. In this respect, the major coalitions such as CUD and UEDF often cited the EPRDF's practice of supporting the less unpopular/splinter group within these organizations raise serious question about its (EPRDF) commitment for the institutionalization of genuine multiparty political process in Ethiopia, in practice. The intention as well as the practices on the part of the incumbent to systematically weaken and attack the beleaguered political organizations outside state power were at the center of the dramatic loss of integrity of electoral process and outcomes ever since. In the post 2005, the problems faced by 'opposition' political organizations can also be explained by the inability of their members including their MPs to reach out to their constituencies, due to active state repression at the local level. Except during the electoral campaigns, officials of 'opposition' political organization could not actively engage with the population at the local level, especially in rural areas, since they were not in a position to freely travel and discuss with their supporters, again due to intimidation, harassment, threats or attacks from the incumbent's functionaries at the local level virtually in all parts of the country. Consequently, apart from the occasional airing of their views in the parliament dominated by the EPRDF during the 2005-2010 period, and the use of private press, they were almost absent from active engagement in the political process( US State Department, 2008).

Another blow to the multi-party political pronouncements in the aftermath of the 2005 period was the new state laws or legislations rubber-stamped by the EPRDF controlled parliament. These include a new electoral law, so called Charities and Societies Proclamation, the Media, Anti-terrorism legislations (Brechenmacher, 2017). As opposition groups and others have continued to complain, observers of contemporary political developments in Ethiopia viewed 
these legislations as harbingers of the narrowing of the political space in the run up to the May 2010 elections, which in turn foretold the outcomes of the 2015 elections. These legislations have been severely criticized for legalizing illegal and repressive practices of state authorities against their political opponents often treated as enemies, real or perceived. The worst manifestation of these controversial legislations was their use in the courts of law in the country by the EPRDF regime against its political opponents. The decrying of the same by independent human rights organization earned them enmity with state functionaries in Ethiopia.

Despite their endless predicament, 'opposition' groups attempted to reorganize and regroup in the run up to 2010 and 2015 elections. They attempted to put together new coalitions to challenge the EPRDF. For instance, members of the former CUD and the former senior members of the EPRDF whom it expelled ${ }^{4}$ established the coalition known as Unity for Democracy and Justice (UDJ) or Andinet in Amharic different from the other coalition named Forum for Justice and Democratic Dialogue (FJDD) or commonly called Mederk in Amharic. As the 2010 elections were approaching, the Ambassadors of the donor countries in Ethiopia tried to bring the EPRDF and some 'opposition' political organizations together for roundtable discussion. The 'opposition' parties were the FJDD, the EDP, the AEUO and the CUD. Later, the FJDD opposed to what was called multilateral/multi party discussions, demanding to engage the EPRDF on bilateral basis. The EPRDF on its part rejected the demand of the FJDD and proceeded to discuss with the rest of the groups. Finally, the EPRDF, the All Ethiopian Unity Organization /AEUO, the Ethiopian Democratic Party/EDP, and the EPRDF affiliated CUD signed a "code of conduct" at the presence of their chairs: Meles Zenawi, Haile Shawul, Lidetu Ayalew, and Ayele Chamiso, respectively (International Press Service, 2009). During the months preceding the elections, the representatives of these 'opposition' groups and the EPRDF debated on several themes on political, economic and social issues. However, unlike the 2005 elections the debates were not given live televised coverage. Meanwhile, some of

\footnotetext{
${ }^{3}$ Ethiopian state authorities often accused organizations such as Human Rights Council (Ethiopian) and the Human Rights Watch as having their own political agenda, and the regime over the years maintained a very tense relations with US State Department due to the latter issuing its annual reports documenting human rights violations in Ethiopia.

${ }^{4}$ Negasso Gidada and Siye Abraha were formerly high ranking EPRDF officials which joined the UDJ.
} 
the 'opposition' in general and FJDD in particular accused the ruling EPRDF and its supporters for harassing their candidates in different parts of the country in the run up to the elections. The ruling EPRDF, nonetheless, in most cases rejected the allegations. Moreover, the National Electoral Board of Ethiopia (NEBE) responded that the allegations were not supported by evidence. Towards the end of March 2010, the EPRDF government and the EU had appeared to have reached an understanding that the latter would send its own election observation mission to Ethiopia, which sent about 150 observers. The African Union (AU) also fielded observers. However, the Carter Center, which observed the May 2005 elections, did not send observers. Despite their precarious conditions and the surveillance, FJDD, the UDJ, the EDP led by Lidetu Ayalew, the All Ethiopian Unity Organization (AEUO) of Engineer Hailu Shawl; the offshoots of the former CUD named the 'parliament group'; and the newly formed organizations such as the Ethiopians' Peace and Democracy Party (EPDP); the Ethiopian Vision Party (EVP); and the Ethiopian National Democratic Movement (ENDM), were among those that took part in the May 2010 elections (Tronvoll, 2011).

In 2010, the EPRDF and allied groups claimed a sweeping victory, taking all but two of the seats for the House of Representatives. The two seats, one in Addis Ababa and another in Bonga, Kafa Zone, Southern Nations Nationalities and Peoples Region, were won by the candidate of UDJ and an independent candidate, respectively.

As far as the reports of the different election observer groups were concerned, first the African Union Observer Mission indicated that while they could not observe the process during the campaigns they reiterated that the NEBE handled the electoral process in a professional manner. Moreover, from what it called polling day observation it noted that the candidates of the ruling EPRDF had their own observers in all polling stations visited while those of the 'opposition' organizations did not have theirs. In citing further irregularities, the AU mission indicated the ballot papers lacked adequate security features and the situation was suitable to manipulation in that the counting procedure and enforcement of existing laws were lacking in some of the polling station they observed. Despite these and other claims of irregularities the AU Mission concluded that the 2010 elections were organized and carried out in accordance with 'AU guidelines and standards for the conduct of democratic elections' (African Union Observer Mission, 2010). It however went on to raise some critical points particularly on the relationship between the ruling party EPRDF and the state/government run by it. In this regard the report mentioned that beyond what has been regarded as the incumbency advantage', the political arena was fully in favor of the EPRDF. It cited the use of 
state resources for the activities of the ruling EPRDF. The EU mission refrained from the full endorsement of the elections by claiming that "the election does not meet certain international standards." The EU, while it claimed the Ethiopian legal setting provides the scope for the conduct of genuine elections, it reiterated that the implementation of the laws was such that it could constrain the enjoyment of the rights and freedoms of the population. The report cited the changes the government instituted to the legal framework, together with other measures, have resulted in the narrowing of the political space (EU Observers Mission, 2010).

To sum up, the 2010 elections were in reality held in a tense situation accompanied with frequent claims of the 'opposition' groups, of harassment, intimidation and death of their members and supporters. In other words, beyond the measured statements of the AU and EU missions, the 2010 elections dashed any remaining hope of Ethiopians of various political persuasions of meaningful multi-party electoral contestations. This state of affairs was a continuation of the practices of the EPRDF, the brutal and clientelist methods with which its networks of functionaries worked to "reclaim" the ground they lost or the "calculated risk" they took in allowing their opponents to campaign 'freely' for the 2005 elections (Leoul, 2006). It entailed disregarding any basic norm of modern democratic politics, including the use of state laws mentioned earlier against not only the political organizations but also members of the society perceived as its opponents. Members of the private media were among those who were hit hard in the run up to 2010 elections, the regime rooting out the few remaining private press issuing critical views (Human Rights Watch, 2015).

Moreover, the use of state institutions especially the courts as an instrument to legitimatize state repression against the political opponent of the EPRDF strikes at the heart of institutional crisis in contemporary Ethiopia. This can best be explained by the grievances of the officials of political organizations such as the Oromo Federalist Congress (OFC) during the 2010 as well as the 2015 elections. The OFC took part in the 2015 elections and fielded relatively larger number of candidates from among the few beleaguered political organizations outside the state power ('Refworld', 2014). In the run up to the elections, the OFC reported its candidates and supporters were intimidated and detained. It was also witnessed that hundreds of the candidates and observers of the 'opposition' groups, under pressure from the regime functionaries declared, usually informally, their withdrawal from the process. Moreover there were reports of wide spread rigging where the OFC in fact claimed to have evidence such as ballot papers thrown into toilets by regime functionaries, and two of its supporters killed on the elections 
day. ${ }^{5}$ The OFC representatives argued that they would no more take the cases to the courts since they claimed the results of any such court proceeding would not be more than rubber stamping of the regime's position. This shows, the level of not only the electoral pretensions and the lack of integrity of the process, but also how the integrity of long standing public institutions were being seriously undermined by the EPRDF in state power and its associates, using the institutions for illegal and narrow group interests (Human Rights Watch, 2010).

The 2015 elections took place in conditions where all state institutions were mobilized to ensure a total victory for the EPRDF and its affiliates, organized by the electoral commission that has been simply enforcing the incumbent's position without any remorse. Under such conditions, it would have been even more difficult to understand how many people may have actually registered to vote, how many actually voted, and how many of the votes were counted properly. There was no way of knowing how many eligible voters did register, or did not vote after registering. The elections itself took place amidst reports of killing of opposition figures, jailing of journalists, activists, imprisonment of opposition observers and mass withdrawal of opposition observers (US State Department, 2015). Overall, the 2015 electoral process that led to a claim of a $100 \%$ electoral victory by the EPRDF and its partners was the logical outcome of the antagonisms, the degradation of basic norms of human dignity, human rights and freedoms, beyond the conduct of periodic elections. The whole process was one of open deployment of totalitarian techniques of unimaginable proportion and the near absolute loss of integrity of not only of the elections but also of the whole institutional as well the political processes of the country. To sum up the elections in 2010 and 2015 in particular were carried out in conditions where all state institutions and public resources were used to ensure EPRDF's and its partners' 'victory' in all regions of the country.

\section{Political Antagonism, Totalitarian Ambition and "Decades of Democratic Pretentions"6}

This section is devoted to reflections on the TPLF dominated EPRDF government as the primary actor responsible for the running of the affairs of the state and its roles in being at the forefront of the propagation of the rhetoric of multi-party elections in Ethiopia for more than two decades. Observations from the synopsis of

\footnotetext{
${ }^{5}$ Information from prominent Oromo Federalist Congress Official

6 See Pausewang et al., 2002.
} 
the political processes centering on the last three general elections in Ethiopia have shown that the positions the regime took on electoral issues as well as other matters affecting the population were the logical outcome of its aims, policies and strategies. Informed by TPLF's experience as an insurgent group, and bolstered by more than a quarter of a century of arbitrary use of state power, the EPRDF intensified its antagonistic relations with the various categories of the population.

The TPLF dominated EPRDF until the 2018 dramatic events often reminded its supporters and opponents that it is a front of political organizations or groups which militarily fought and won a protracted war against the militarysocialist regime the Derg in power in Ethiopia for about 17 years. EPRDF's core group before 2018 in particular, the TPLF, came to organize itself and operated against the Derg in a hostile political environment in the 1970s and 1980s. As a consequence, while its victory over the Derg resulted in a sense of invisibility of its leadership and inflated self-image of its rank and file, the TPLF led EPRDF regime for a long time characterized the prevailing political environment in Ethiopia, the views of the political organizations dubbed opposition, as well as individual and group members of the society perceived to be unsympathetic to its policies and practices in the post 1991 period, as hostile and inimical to its policies and strategies to achieve "peace, democracy and development". Until early 2018 dramatic events that followed a period of sustained popular protests (2014-2017), the EPRDF leadership could not change such an attitude towards those it often regard as "anti-peace, anti-democracy and anti-development" forces or "the forces of destruction". These characterizations were willfully used against political groupings including those it "recognized" at different periods to take part in the political processes including in elections as discussed. No political organization or group capable of staging even the slightest challenge to it could have escaped such demonization. The same applies to any observation of dissent among individuals and groups within the society. The characterization of the latest deadly protests during 2014-2017 period as a work of "anti-peace", "anti-development" and "antidemocracy" or the work of "forces of destruction" was part of the continuation of its ambitious agenda aimed to establish a total control over the Ethiopian political scene and its incapacity to learn lessons from its practices and misdeeds over the years in this respect. In doing so, it heavily relied on its past experiences in maintaining control of its organizational structures and deploying the same in controlling the population.

The EPRDF until the 2018 dramatic changes used to assert that its policies and practices earned it successive victory in the post-Derg Ethiopia (Addis Raey, 2002 E.C). The regime has been frequently reminding the population that it 
addressed long standing grievances of the various "nations, nationalities and peoples" against the oppressive state in Ethiopia in the past. This refers to the reorganization of the pre-1991 Ethiopian state and the establishment of regional states (Kelleloch in Amharic), and in some cases "special Zones" or Woreda's in the names of the 'the peoples' of these regions or 'Kelleloch'. The political organizations in charge of the regional states or the 'PDOs' which professed to be the leaders of the 'peoples' would argue that the regions they are in charge of have achieved a measure of self-determination, though this could not be more than a self-serving claim. Although such forces coalescing around their expressed gains in terms of "self-determination" have not been monolithic, they were constantly reminding "the nations, nationalities and peoples" of their achievement in this regard and used this as an instrument to coax, persuade and lead the 'peoples' along the road of 'peace', 'democracy' and 'development' as defined by the EPRDF. Thus banking on its own archaic tradition of control and repression, the former EPRDF until early 2018 portrayed its image as a redeemer, that it was the path to political, economic and social progress, and that there would not be another choice or alliterative than itself. It was transmitting publicly the same message with a view to induce the general public hinting that the 'opposition' or political forces outside state power should not be given a 'free ride' across the political landscape. This observation was further corroborated by the views of the critics being published following its announcement of victory after the successive elections. In the eyes of one of the critics, "it saw itself as the small elite - the selfproclaimed avant-garde - with the right and duty to direct the 'development' of the 'broad masses', which meant the mass of peasant farmers' to lead them out of poverty" (Lefort, 2010). To sum-up, the practice of reminding the members, supporters of the EPRDF, and the general public, of the danger of allowing the forces perceived to be aiming to destroy what they gained hitherto, for a long served as its 'winning' strategy.

Such a strategy heavily relied on the support of the individuals and groups that assumed to have been rallying behind TPLF-EPRDF's ethos of state, society and politics and the surging clientelist dealings in the post-Derg period responsible for the creation of dependent categories of beneficiaries - the "rent seekers". This in effect means rewarding these groups by distributing the spoils, at the same time denying its perceived opponents any space to organize, operate and express themselves freely. Following from this, at one level, the post 1991 political development witnessed the fusion of EPRDF as political organization and the state in Ethiopia. For individuals and groups within the ruling EPRDF, it was therefore not uncommon to utilize state resources for the benefit of the organization, to 
propagate its policies and program often confused with the interests of the public, thereby institutionalizing the practices of favoritism which the EPRDF itself was lamenting, as a political economy of "rent seeking" (EU Election Observation Mission, 2010). Beyond what has been regarded as the incumbency advantage, state institutions were undoubtedly served as a locus of mobilization of support and of resources for the EPRDF which under a strict legal condition would have been unacceptable. The use of state resources for purposes other than the one for which they were originally intended has had a far reaching consequence for the elections and beyond. This 'empowered' state officials' to embezzle and allocate economic resources such as finance, land and job opportunities to members and supporters (Human Rights Watch, 2010). This bolstered the political economy or context in which favoritism has got its way into the social and political life of the society on the one hand and the alienation and suppression of those with differing views on the other. Hence, it led to the intensification of the antagonism in the relations between the state-the EPRDF- and the various categories of the population.

Beyond EPRDF's political repression and abuse of public institutions through its intrusive politico-security structures, it created new structures of control of individuals and groups within the society. What have been named "command post" and a "one- to-five organizing" of the population were among the most infamous forms of coercive mechanisms that aimed for the total control of the population by the EPRDF regime. The official objectives of the formation of such structures were often presented by the EPRDF functionaries as "the building of development army." These means that each and every adult individual is required to be categorized into a group of five people, the reports of which are going to be sent to a central "command post" (Brechenmacher, 2017). Observers and opposing political groups indicated that the use of these structures of control by the regime worked to their disadvantage, the consequence of which was the regime declaring a near total electoral victory in the 2010 elections. Worse still, the EPRDF has not been deterred from using such infamous structures of control to achieve the $100 \%$ electoral result in the 2015 elections. While such structures created a sense of invincibility and a self-deceptive image of consolidation of control on state institutions, societal formations, individuals and groups within the 
society, in reality however voter intimidation included regime functionaries' going door to door during election days to coerce reluctant residents to vote. ${ }^{7}$

In the aftermath of the 2015 elections, nothing could have explained the pretensions of the EPRDF than the conduct of senseless meetings and 'negotiations' with pseudo opposition groups to reform the electoral system, while incarnating individuals and groups which relatively challenged it during the 2015 elections (Walta Information Center, 2017). The regime was propagating the importance of reforming the electoral systems, including holding talks about proportional representation, while the people were demanding the end to killings, mass detentions and displacements. This was at a time human rights organizations have been consistently expressing their misgivings about the closure of what has been often characterized as the political space (Human Rights Watch, 2016). The protracted defamation of the private media, and the ambition to totally control all space of expression and association had chilling effect and did instill fear, fragmentation and distrust within the population until the start of sustained societal responses to state repression during the 2014-2017 period. In general, the points mentioned above are indicative of the former EPRDF regime's inability to learn any meaningful lesson from the misdeeds of its predecessors, its own totalitarian ambition, and practices of a quarter of a century rule of the population who have been left with little option than confronting it.

To sum up, the fundamental basis of the TPLF-EPRDF regime's relations with the society in Ethiopia has been characterized by antagonism in which the interests of the state diverged from the needs and the aspiration of the overwhelming majority of the population. Not many would have taken the regime's rhetoric of 'democracy', 'peace' and 'development', seriously in the aftermath of 2015 elections, which is indicative of the alienation of the overwhelming majority of the population from the political as well as the policy processes of the regime. Ironically it was EPRDF's rhetoric and practices about 'development' which in the eyes of members of the population amounted to land grabbing, that resulted in a mass protest that rattled the regime and forced it to make concessions by the end of 2017 (Human Rights Watch, 2010). As discussed in the next section, mass protests especially during 2015-2017 were not just spontaneous reactions to state repression; they were the consequences of prolonged antagonism in which the regime disregarded basic norms of human dignity,

7 The writer of this article observed state local officials going to door-to-door in neighboring hood systematically urging people to go to polling stations, doing the same at least 2-3 times on the same date.

112 
freedoms and the rule of law, in addition to its unwillingness to conduct free and fair elections.

\section{Constraints to Political Transformation \& Multi-party Elections in the Post 2014-2017 Protests}

Central to the political dynamics of change since early 2018 was the popular protests that shook the core of the regime led by Hailemariam Desalegn. The widespread protests carried out on a sustained basis the Oromia and the Amara regions were consequential in forcing the regime to make concessions. As repressive state actions that involved arbitrary killings, torture and mass detentions continued, the protests became even more persistent and exhibited some level of coordination. More and more people from the different Oromia regions and later the Amhara regions of the country have been involved and the population in these parts of the country did bear the brunt of the repression born out of desperation of those in control of state power. Activists from abroad played significant role in galvanizing and emboldening the protests at home amidst the crackdown. The dayto-day activities of state institutions, travels from the capital Addis Ababa to different regions of the country were disrupted; rioters attacked and in some cases burnt down properties (BBC, Aug. 22, 2016). In response, the state military and security forces killed hundreds of people, injured and detained tens of thousands. Towards the end of 2017 it became apparent that the regime was not in a position to sustain the status quo in repressing the population. The pressures from within and outside the country led to the resignation of Hailemariam Desalegn. Abiy Ahmed from the Oromo Peoples Democratic Organization (OPDO) wing of the EPRDF took the prime ministerial position in April 2018, followed by dramatic events and promises which among others include the promises for the creation of a political environment whereby free and fair elections could be held, in anticipation of the general elections in 2020.

Political prisoners were released in thousands, armed political organizations in exile have returned to take part in peaceful political struggles, hundreds if not thousands of people who were in exile have been able to return or visit the country ${ }^{8}$. Abiy Ahmed's administration took initiatives towards the reconciliation of deeply divided religious communities, held meetings in Europe and America with members of the Ethiopian emigrant population, some of the

\footnotetext{
${ }^{8}$ It has been reported that more than 100,000 people have been released, about 40,000 pardoned, and about 10 political organizations, mainly armed groups from Eritrea, returned.
} 
events which saw the largest number of people attending in the presence of the Ethiopian government official in the post 1991 period. A modicum of press freedom and of expression restored thanks to the sacrifices paid by members of the society who fought the naked repression of the state and forced the EPRDF regime to make concessions. Significant numbers of women have been assigned to ministerial positions and some individuals perceived to be outside the traditional EPRDF circles have been appointed to various positions. The archetype political control on public institutions, groups and private lives of individuals has been eased, at least for now. The rapprochement with Eritrea has been positively received at home and abroad and relations with Middle Eastern countries such as United Arab Emirates and Saudi Arabia have been on the upbeat (US Institute of Peace, 2018).

Since April 2018 some of the elements of the political rhetoric of the EPRDF led by the administration of Abiy Ahmed have changed. The political language has become one of promoting unity than harping on EPRDF's divisive rhetoric's "anti-peace", "anti-development", "anti-democracy" which have been replaced by the language of Medemer or unity. Given the former EPRDF's language of antagonism, the change of tone seems to have brought significant relief to the public. The practice of branding the regime's perceived political opponents, particularly supporters, members and officials of political organizations as "anti-peace", "anti-democracy" and "anti-development forces" has been changed to "competing political parties." The constant intimidation and harassment of officials of political organizations ended and previously armed political organizations returned from Eritrea are reportedly opening offices in different parts of the country, despite tensions in the relationships between the new ruling grouping of EPRDF and some of those who returned from Eritrea in particular. ${ }^{9}$ This experience of relief during the last one year period has not been without challenges, however. Distrust of the EPRDF, the activities of state authorities and the political process in general, fragmentation of political organizations and political ideas, and the erosion of the rule of law, are identified as some of the major challenges in the present context with far- reaching implication for the future of multi-party politics and transformations in state-society relations in Ethiopia.

\footnotetext{
${ }^{9}$ Frictions between the OPDO, now ODP wing of the EPRDF and the OLF faction led by Daud Ibsa since mid-2018 led to conflicts and armed confrontations on occasions leading to misgivings among the population that have been severely affected by state repression in areas or regions such as West Wollega.
} 
As mentioned above, trust in the political process led by the EPRDF, fragmentation of political organizations and political ideas or views they espouse and the erosion of the rule law are among the major challenges in the present context. First of all, the distrust among the public as well as political organizations, of the EPRDF as political organization, its policies and practices remains pervasive. The legacy of state repression and arbitrary exercise of power have continued to cast shadow over the relative sense of relief felt among the wider public following a period of mass protests resulting in some of the positive developments mentioned earlier. It is also important to mention that hundreds of thousands of people have been displaced from different parts of the country both before and after 2018 (ReliefWeb, Sept. 12, 2018). Such conditions and uncertainties feed into past and recent experience of the people in distrusting those in power. Put differently, the major political events or changes since 2018 while addressing some of the problems, did not tip the balance in favor of the people to have control over political affairs of the country, their aspirations and demands for freedom, the rule of law and human dignity and human rights. This means that while one of the central political issues raised since the changes in early 2018 has been transition to democratic rule through the mechanisms of free and fair elections, conditions of distrust continue to prevail including skepticism about the future of free and fair election in this country.

From economic point of view, the much talked about developmental state economy in reality amounted to the domination of the economy by individuals and groups affiliated with the regime dominated by the TPLF. The government was using extra-legal means to benefit members of the regime and their dependent beneficiaries, networks extending to the local level in the society, while at the same time denying the basic means of subsistence of the perceived opponents. As mentioned, protests which started in 2014 were primarily initiated by what local people understood as state-sponsored dispossessions of their economic means of subsistence, notably land, contrary to the much proclaimed 'developmentalism' of the EPRDF regime, that received acclamation from its local and global clients and patrons before 2018. Thus, the cumulative effect of controlling, co-opting state and societal institutions and arbitrary use of state power left members of society with no options than facing the regime head-on, conducting sustained protest led by individuals and groups echoing the voices of the highly disaffected population (Human Rights Watch, 2017). In other words, while the mass protests of 20142017 was the continuation and outcome of the accumulated effects of a quarter of a century of EPRDF's rule, mismanagement, and pseudo reforms including "decades of democratic pretentions," the current reform initiatives of the new EPRDF 
administration working to restore trust in state institutions that have long been eroded is proving to be challenging (Pausewang et al., 2002). Put differently, while it seems that the reform initiatives have been viewed positively, and expected to improve some aspects of the relations between the regime and the population, and revitalize institutions (Yeraswork, 2006), if and when carried out on a sustainable basis, the backlog of experience of controlling, co-opting and infiltrating institutions, including political organizations, traditional societal institutions inimical to the ideals of modern democratic practices including free and fair election, are militating against the reform initiatives as current observations suggest. Moreover, while the reform initiatives have been positively received by large section of the population, there has also been widespread feeling among the population of continuing lack of responsiveness, accountability, transparency of state officials or institutions at the national and sub-national levels. Such problems have been the sources of misgivings and in some cases protests held by members of the population in different parts of the country since 2018. In general, the lack of trust on the part of the general population of the EPRDF as political organization (not necessarily all individual officials at the forefront of the reform initiatives currently), their relations with state institutions at various levels will remain a major obstacle in visualizing a new framework of politics in which, it is hoped, free and fair elections may be held in the near future.

The second major constraint in thinking through the prospect of meaningful multi-party political dispensations or multi-party politics is the fragmentation of political organizations and political views and ideas. Outdated methods of political control and repression carried out by the EPRDF regime and prolonged stay in power contributed to the fragmentation of political organizations and opinions degenerating into sectarian politics. In addition to EPRDF's own divisive maneuvers during the successive elections discussed earlier, the Kellels or Regions controlled by EPRDF 'partner' organization in Ogaden, Afar, Benishangul Gumuz, and Gambella served the purpose of preventing opposition political organizations from taking part in political activities in these regions including during periods of elections (Zemelak, 2017). EPRDF's strategy of control went to the extent of discrediting political organizations which professed to have national platforms by demonizing them as lackeys of those accused of pursuing old unitarist political model of the country, besides those it often branded as "narrow nationalists"- terms frequently used against its real or perceived opponents.

Besides, the formation and function of political organizations including those that have taken part in electoral processes so far are not based on shared 
notions of political ideals in Ethiopia at the national level. The fragmentation of the organizations and their views extend to the lack of consensus on the meanings of citizenship, collective and individual rights, the status of some of the most controversial provisions in the constitution, the nature of borders and solutions to territorial claims and counter claims along the borders of the post 1991 Kelleloch or "National Regional States." There are extreme positions in which some political organizations identifying themselves with one or another categories of the population in the context of the prevailing politicization of identities on one hand and those full of nostalgia of the unitarist model of state and government of the past and the gulf between the two animating tensions among the organizations call themselves 'front', 'movement', 'party', etc.

Moreover, the prevailing political thinking and practices of deploying the "language of identity" to exploit the presumed differences among the diverse population as an instrument of political power by the former EPRDF regime is being imitated by various individuals, networks and groups espousing parochial political agendas. In the present context, such regressive practices have the potential to impact not just the political reform initiatives and the activities of political organizations but also the efforts aimed towards building political solidarity among the diverse population as evidenced by societal responses to state repression during the recent protests. There are growing fears that the people assumed to be not "natives" to certain regions of the country may not be able to feel free to participate in political activities in the regions, and political organizations outside state power may not be able to move freely and seek support in different parts of the country (US Department of State, 2007). In a nutshell, the legitimization of political organizations and ideas along sectarian lines and the 'instrumentalization' of the identities of one or another of the constituent population of the country for seizing, maintaining and use of state power has had a long term impact in reinforcing the sense of alienation, fear and distrust within the population experienced during much of EPRDF's rule.

Beyond the damage that has been done already largely due to the former EPRDF's antagonistic approaches to politics, political groupings in and outside state power as well as newly emerging groups are being indulged in the practices of interpretations of political ideas and terminologies in a manner intensifying the fragmentation and disunity and engage each other on sectarian or parochial lines. The pervasive use of terms such as "nation" or "biher" in Amharic without adequate understanding of such controversial notions will have implications and will continue to raise serious questions, including questions about the prospect for genuine multi-party political dispensations in Ethiopia for the time to come. It is 
therefore not surprising that currently some political organizations and their supporters and political activists, knowingly or unknowingly, are attempting to expand the scope of their parochial political attitudes and practices to create tensions and conflicts among groups within the wider society risking the further fragmentation that would put in doubt the feasibility of free and fair elections during the anticipated 2020 general elections, at least.

To sum up on the issue of fragmentation of political organizations and political ideas, the diverging interest of those in control of the state's political, economic and social development policies and practices for a long time has been the outcomes of political antagonism including the deliberate distortions of political concepts to fit the purposes of the narrow interests of the EPRDF regime, its beneficiaries, being imitated by other groups organized along sectarian lines. Consequently, the use of extremely divergent political positions and pronouncements by officials, members or supporters of the various political organizations in and outside state power as means of political mobilization and the route to power will have a significant bearing on the effort aimed towards the creation of a balanced context including the creation of common understanding about the imperatives of a genuine multi-party elections as the basis of assuming political offices in the future. It is therefore not surprising that those members of the public who have been aware of the divisive effect of the fragmentation of political organizations and their rhetoric have ironically been calling for unity among political organizations. The most recent example has been the appeal of members of the Oromo community for the "unity of" political organizations, professing to stand for the interests of members of this community. It seems that the fear of members of the community became a reality when the distrust between the OLF faction led by Daud Ibsa and EPRDF's regional block, the Oromo Democratic Party (ODP) (the former OPDO) entered into armed confrontations resulting in loss of civilian lives, closure of schools, bank robberies and burnings of public offices during the late 2018, especially in western Wollega region. Therefore, the question that remains is whether the EPRDF and other political organizations or groups have learnt any lesson from the 25 years of fragmentation and disunity characteristic of state-society relations of antagonism explained in this paper.

Third, one of the major challenges in conducting genuine multi-party elections and in the overall improvement of state-society relations in Ethiopia is the erosion of the rule of law. The malpractices extend beyond the rampant use of state laws as instrument of repression in pre-electoral, electoral and post electoral periods widely documented by human rights organizations and others who 
conducted studies on this particular register of the regime. One of the major negative lessons of the 2005 elections has been new state laws which restricted and curtailed basic rights and fundamental freedoms of individuals and groups in society. In a bid to discourage or punish individuals and organizations that were perceived to have been sympathetic to its opponents, EPRDF came up with what were regarded as civil society, media and later anti-terrorism laws (Hussein, 2017). Using the "legislations" as instruments of political repression and the use of the courts of law as political instrument severely impacted popular perception of laws and legal institutions with long lasting repercussions (Open Democracy, Nov. 2012). Among others, the anti-terrorism legislation was one of the most unpopular legislation since the regime used it widely as a tool to punish its political opponents and to remain in control indefinitely. The use of such legislations led to severe criticisms of the regime, and its practices of total control of state institutions including the judiciary, the co-optations of societal institutions (including those working in the domains of customary laws - traditional as well as religious institutions) will continue to have long term repercussions.

Thus, some aspects of the recent initiatives toward the restoration of the rule of law are encouraging, and appointment of new prosecutor and Supreme Court judges, new electoral board members, establishing national reconciliation commissions are positive gestures. However, these do not seem to have immediate impact on the situation on the ground and perhaps that is why the people must continue to appeal to the current administration for the restoration of the rule of law, as a matter of priority. This means that it would be difficult to anticipate a major change in the political landscape including in the fields of electoral politics, without genuinely working on the restoration of the rule of law whereby people can freely express themselves, make associations and achieve a measure of economic freedom, peace, and sustainable development under the rules of law. Moreover, this is in as long as addressing the daunting task of the restoration of the rule of law is understood to contribute towards the creation of an enabling context for multi-party political processes as essential component of democratic politics in the future. To sum up, recent experiences suggest that addressing problematic issues in regards to the restoration of the rule of law, overcoming the challenges of political fragmentation and the lack of trust in the political process in improving the prospects of democratic politics would require more than the good will of political groups or organizations and political reform initiatives led by state officials. More than anything else, the situation requires reflections on the significance of the notion of political community in Ethiopia, the foundation of 
which are human dignity, human rights and freedom, the rule of law, justice, as briefly discussed next, in the conclusion.

\section{Conclusion: the Quest for Political Community in Ethiopia}

The analyses on the topics of electoral politics and multi-partism and the nature of state-society relations in Ethiopia indicate that there has been fundamental divergence in the relations between the various categories of the society in Ethiopia and the regime led by the EPRDF that used various strategies of control and repression to prolong its rule for more than a quarter of a century. Its strategies of power and control led to fragmentation, fear, distrust, and the eventual alienation of the population from the political process and reduced its rhetoric of multi-party elections to nothing more than pretentions referred to in this paper as multi-partism. The regime's rhetoric of multi-party democracy that lasted for more than two decades was discredited beyond doubt following the 2010 and 2015 elections. Ironically, such a dire situation has on occasions been accompanied with false acclamation from the outside, when the regime declared a $100 \%$ electoral victory. ${ }^{10}$ EPRDF practices which led to the lack of respect for the dignity, the rights and freedoms of members of the society, their voice in the political process eroded the people's sense of meaningful citizenship, and threatened to render meaningless the notion of the will of the people.

Thus, one could observe the circumstances in which nothing would have changed the situation than the coming together of members of the disaffected population to confront the repression. While the disunity and fragmentation caused for more than 25 years of EPRDF rule will continue to raise questions about the viability of political community in Ethiopia at the national level, it appeared that the people's realization of their own determination to stand in solidarity with one another served as a watershed in response to state repression, the regime's arbitrariness, lack of accountability, lack of meaningful participatory political processes. In other words, the people's demand of dignity, freedom and the rule of law that animated the protest resulting in a modicum of change since 2018, has created some signs for the creation of political solidarity as key element in the rethinking of political community in Ethiopia. The central features of those protests which led to some level of relief for about a year now arose from the effort

\footnotetext{
${ }^{10}$ The Former US President Barack Obama's description of the EPRDF government after the May 2015 elections in Ethiopia, as "democratically elected government" is the most dramatic of all the uncalled-for acclamations.
} 
made by the affected population to stand together against state repression. The people in the regions where state repression had been relentless, before and after the successive elections, and where 'opposition' political organizations put relatively stronger challenges to the regime ${ }^{11}$, were at the forefront of the protests and borne the brunt in terms of the death of hundreds of people during the protests. Put differently, while repressive regimes and their proponents have always been skeptical about the people's capacity to stand together and respond to the repressive actions of the state, the protest since 2014 that created a shockwave within the political order confirmed people in unison can make a difference.

The protests thus served as a "relational" moment for the ones marginalized population to rise to the occasion and take actions directed towards ending state repression. During the protests, it was observed that more repression on the part of the state meant even more emboldened actions accompanied with some level of coordination and solidarity including attempts to build trust across the political divides. The people who are at the forefront were persistent in their demand, namely the demand to end the killings, state-sponsored dispossession, demand for release of political prisoners, political freedom, restoration of the rule of law, dignity, accountability and justice. More important, it put the regime on the defensive which at times was claiming the protests were without "owners" or 'leaders', which was indicative of the fact that the unfolding of the protests were essentially mass based, even though there were encouragements and activism that attempted to provide guidance from outside the country in particular. This is an indication of a modicum of change, a 'relational moment', of the people's capacity to create space of discussion, association and solidarity even in conditions where the political environment was openly repressive. This underwrites an important point that was neglected before, i.e. the possibility of a community of people overcoming fragmentation, mistrust, and fears of the state, waging their struggle with determination and coordination.

The promise of the community of people standing in solidarity with one another, working to transform the relations with repressive state machinery is not easy; it requires continuous engagement in the creation of the space for expression, association, and discussion on what to do next in politics, despite the ongoing challenges. Such engagement need to be visualized as long term project in dealing with the challenge beyond the times of elections and protests, requiring the

${ }^{11}$ These arguably refer to West Shoa, Wollega, and Western Arsi, West and East Hararge and other regions of the country at the center of the protests against the regime since the 2005 elections. 
understanding of the ongoing dynamics manifesting itself in parochial attitudes and practices which appear to be pervasive even after the reforms have been initiated. Overcoming the experiences of fragmentation, dealing with the divisive and sectarian rhetoric of political groups in and outside the state power, regressive calls of self-appointed activities sowing the seeds of discord are the obstacles which stand in the way of the quest for a viable political community in Ethiopia. It is primarily a quest for space of association, expression and solidarity which nurtures human dignity, human rights and freedom, rule of law and justice, fostering meaningful sense of belonging and citizenship in a 'relational'- ethical realm.

Thus the future of a genuine multi-party electoral dispensations as an important component of democratic politics in the future will by and large depend on the capacity and effort among the diverse people of the country to engage in inclusive dialogue, stand in solidarity with one another for the common causes of dignity, freedoms and the rule of law, and justice, without which meaningful elections and the overall transformation of politics would remain unattainable. Political reform initiatives and attempts to reform the once infamous electoral board and the ongoing conduct of dialogue with the various political organizations may be viewed as positive steps to improve the conditions in which future elections can be held in Ethiopia. Nevertheless, the issue of meaningful electoral process to conduct genuine multi-party elections and resolving some of the most intractable political problems faced by the people will be challenging for the years to come, and, given the experiences and the current dynamics, it may not augur well for the outcomes, including the outcome of upcoming 2020 general elections the successful or timely conduct of which in itself is in doubt. Without being overly prescriptive, more than anything, the situation requires the recognition of the role of the various categories of the population to come together and stand in solidarity for the common purposes and goals of a political community the foundations of which are human dignity, freedom, the rule of law and justice. 


\section{References}

Abbink, J. (2006). Discomfiture of democracy? The 2005 election in Ethiopia and its aftermath. African Affairs. 105 (419), 173-199.

Addis Raey. (2002 E.C). Mircha 2002 ena estrategiawi tekemetaw [Election 2002 \& its strategic significance]. Addis Raey, A Publication of EPRDF, 3 (3).

African Union. (2010). Preliminary statement of the African Union Observer Mission on the Ethiopia legislative elections of May 23 2010. Retrieved from https://au.int/ar/node/36683, accessed Sept. 2018

Amnesty International. (2006). Ethiopia report. Retrieved from https://www.refworld.org/docid/44ff7a62f.html

Aregawi Berhe. (2008). A political history of Tigray People's Liberation Front (1975-1991): Revolt, ideology and mobilization in Ethiopia. (Unpublished PhD Dissertation). Amsterdam: Amsterdam University.

Arian, Alan, \& Samuel H. Barnes. (1974). The Dominant party system: A neglected model of democratic stability. The Journal of Politics. 36(3), 592-614.

Arriola, L. R. (2007). The Ethiopian voter: An assessment of economic and ethnic influences with a survey data. International Journal of Ethiopian Studies. 3(1), 73-92.

Arriola, L. R. (2003). Ethnicity, economic conditions, and opposition support: Evidence from Ethiopia's 2005 elections. North East African Studies[Special issue]. 10(1), 115-144.

Baker, G., \& Jens B. (Eds.). (2009). The Future of Political Community. Oxfordshire: Taylor \& Francis.

BBC. (2016, August 22). What is behind Ethiopia's wave of Protest? BBC News. Retrieved from https://www.bbc.com/news/world-africa-36940906.

Bear, C. (2001). Assessing the consequences of electoral democracy: Sub-national legislative change in Mexico. Comparative Politics. 33 (4), 421-440.

Blaydes, L. (2006). Who votes in authoritarian elections and why? : Determinants of voter turnout in contemporary Egypt (Conference paper for Annual Meeting of the American Political Science Association, Aug. 31-Sept. 3 2006). Philadelphia: PA.

Bogaaards, M. (2008). How to classify hybrid regimes? Defective democracy and electoral authoritarianism. Democratization, 16(2), 399-423.

Bogaaards, M. (2004). Counting parties and identifying dominant party systems in Africa. European Journal of Political Research. 43(2), 173-197. 
Solomon Mebrie

Brechenmacher, S. (2017). Civil society under assault: Repression and responses in Russia, Egypt and Ethiopia. Washington D.C: Carnegie Endowment for International Peace.

Carter Center. (2009). Observing the 2005 Ethiopia national elections (Final report). Georgia: Atlanta.

Dahl, R. (2001). Can international organizations be democratic? A skeptic's view. In Ian S. and Casiano H.-C. (Eds.), Democracy's Edges (pp. 19-36). Cambridge: Cambridge University Press.

Dahl, Robert. (1989). Democracy and Its Critics. New Heaven: Yale University Press.

'EU Election Observation Mission'. (2010). Preliminary statement of the European Union election observation mission-Ethiopia 2010: House of Peoples' Representatives and State Councils Elections. Retrieved from http://www.eods.eu/library/PS\%20ETHIOPIA\%2025.05.2010_en.pdf

Friedrich Ebert Stiftung (FES). (2010). Institutionalizing political parties in Kenya. Retrieved from https://library.fes.de/pdf-files/bueros/kenia/07885.pdf

Green, K. H. (2010). The Political economy of authoritarian single party dominance. Comparative Political Studies. 43(7), 807-834.

Human Rights Watch. (2017). Fuel on fire: Security force response to the 2016 Irreecha cutlural festival. Retrieved from

https://www.hrw.org/sites/default/files/report_pdf/ethiopia0917_web.pdf

Human Rights Watch. (2015). Journalism is not crime: violations of media freedom in Ethiopia. Retrieved from

https://www.hrw.org/report/2015/01/21/journalism-not-crime/violationsmedia-freedoms-ethiopia

Human Rights Watch. (2010). One hundred ways of putting pressures-Violations of freedom of expression and association. Retrieved from

https://www.hrw.org/sites/default/files/reports/ethiopia0310webwcover.pdf

Human Rights Watch. (2010). Development without freedom: How aid underwrites repression in Ethiopia. Retrieved from

https://www.hrw.org/sites/default/files/reports/ethiopia0310webwcover.pdf

Hussein Ahmed Tura. (2017). The impact of Ethiopia's anti-terrorism law on freedom of expression (paper for $5^{\text {th }}$ international conference of $\mathrm{PhD}$ students and young researchers). Vilnius: Vilnius University, Faculty of Law.

Husserl, G. (1939). The political community versus the nation. Ethics, 49(2), 127147. 
'International Press Service'. (2009, December 08). New elections code sparks Furor. Reported by Omer Redi of the International Press Service. Retrieved from http://ipsnews.net/news.asp?idnews

Kalpokas, I. (2016). The question of ordering: Creativity and limitation in political communities, (PhD Thesis). United Kingdom: University of Nottingham.

Kou, C.-W., \& Chieh K. (2011). Electoral authoritarianism in the third wave of democratization: Concepts and regime trajectories (conference paper for Northeastern Political Science Association annual meeting, Nov. 17-19, 2011). Philadelphia: PA.

Lefort, Rene. (2010). Ethiopia's election: All losers. Open Democracy. Retrieved from

https://www.opendemocracy.net/ren\%c3\%a9-lefort/ethiopias-election-alllosers

Leijssenaar, B. (2017). The demos as political subject. Netherlands Journal of Legal Philosophy. DOI: 10.5553/NJLP/221307132017046001004

Linklater, A. (1998). Transformation of political community: Ethical foundations of the Post-Westphalian era. Cambridge: Polity Press.

Lyons, T. (2010). Ethiopian elections: Past \& future. International Journal of Ethiopia Studies. 5(1), 107-121.

Lyons, T. (2005). Implications of the May 2005 elections for the democratizations programs. Washington D.C: IFES.

Maimire Mennansemay. (2005). Ethiopian political theory, and surplus history. International Journal of Ethiopian Studies. 2(1), 1-32.

Makinda, S. M. (1996). Democracy and multi-party politics in Africa. The Journal of Modern African Studies. 34(4), 555-573.

Menocal, A. R. (2014). What is political voice, why does it matter, and how can it bring change? (Development Progress Discussion Paper). London: Overseas Development Institute.

Sengupta, S. (2018, September 17). Can Ethiopia's new leader, a political insider change it from inside out? The New York Times.

Retrieved from https://www.satenaw.com/political-unrest-ethiopia-failuretop development-approach/

Norris, P. (2015). Why electoral integrity matters? The Canadian Journal of Sociology. 40(3), 391-394.

Awel Allo. (2012, November 30). The politics in Ethiopia political trials. Open Democracy. Retrieved from https://www.opendemocracy.net/en/politicsin-ethiopias-political-trials/ 
Pausewang, S., Kjetil, T., \& Lovise, A. (Eds.). (2002). Ethiopia since the Derg: A decade of democratic pretension and performance: London: Zed Books.

Pausewang, S., \& Kjetil T. (Eds.). (2000). The Ethiopian 2000 elections: Democracy advanced or restricted (Human Rights Report No.3). Oslo: Norwegian Center for Human Rights.

Pettersen,E., \& Elisabeth S. (2006). Ethiopian parliamentary elections (Nordem Report No.9, 2006). Oslo: Norwegian Center for Human Rights.

Refworld. (2014). Ethiopia: The Oromo Federalist Congress (OFC), including aims and objectives, leadership, structure; information on how to become a member; treatment of members and supporters by authorities (ETH105476.E). Canada: Immigration and Refugee Board of Canada. Retrieved from https://www.refworld.org/docid/589450634.html

Reliefweb. (2018). Ethiopia tops global list of displacement in 2018. Retrieved from https://reliefweb.int/report/ethiopia/ethiopia-tops-global-list-highestinternal-displacement-2018

Rothstein, B. (2009). Creating political legitimacy: Electoral democracy versus quality of government. American Behavioral Scientist. 53(3), 311-330.

Ryan, S. (2016). Electoral authoritarianism and political unrest. International Political Science Review, 37(4), 470-484.

Shapiro, Ian. (2001). Group aspirations and democratic politics. In Ian S. and Casiano H.-C. (Eds.), Democracy's edges (pp. 210-221). Cambridge: Cambridge University Press.

Smith, L. (2007). Political Violence and democratic uncertainties in Ethiopia (Special Report, 192). Washington DC: United States Institute of Peace.

Solomon Mebrie. (2007). State-society relations \& Human rights in Ethiopia: A critique of state-centered approach (Unpublished $\mathrm{PhD}$ Dissertation). Manchester, the University of Manchester.

Leoul Mekonen. (2006, September 11). Bring Ethiopia's Zenawi to justice. Sudan Tribune. Retrieved from www.sudantribune.com/spip.php?article17531

Tronvoll, K. (2011). The Ethiopian 2010 federal and regional elections: Reestablishing a one party state. African Affairs, 110 (438), 121-136.

Vaughan, S. (2011). Revolutionary democratic State Building: Party, people and state in EPRDF's Ethiopia. Journal of Eastern African Studies, 5(4), 619640.

Stigant, S., \& Knopf, P. (2018). Ethiopia-Eritrea peace deal brings hope to the Horn of Africa (Analysis and commentary). Washington DC: United States Institute of Peace. 
Retrieved from https://www.usip.org/publications/2018/08/ethiopiaeritrea-peace-deal-brings-hope-horn-africa

US State Department. (2015). Country report on human rights, Ethiopia. Washington DC: Bureau of Democracy, Human Rights and Labor.

US State Department. (2008). 2008 human rights report: Ethiopia. Washington DC: Bureau of Democracy, Human Rights and Labor.

US State Department. (2007). Ethiopia, 2006 country report. Washington DC: the Bureau of democracy, human rights and labor. Retrieved from https://www.state.gov/j/drl/rls/hrrpt/2006/78734.htm

Vaughan, S. (1994). The Addis Ababa transitional conference of July 1991: Its origins, history and significance (Occasional Paper No.51). Edinburgh: Center for African Studies.

Walle Engedayehu. (1993). Ethiopia: democracy and the politics of ethnicity. Africa Today. 40(2), 29-45.

Walta Information Center (2017). Parties negotiate on mixed electoral system. Retrieved from http://www.waltainfo.com/news/editors_pick/detail?cid=34035

Yemane Negish. (2010). Ethiopia between Election Events: The impact of the 2005 and 2010 pre-elelctions on competitive elections. (Unpublished MA Thesis). Addis Ababa University, Department of Political Science and International Relations.

Yeraswork Admassie. (2006). "Institutions, political freedom and development in Ethiopia." [Monograph] (Yonas Admasu, Trans.). Lisane Economics, 8(6), 20-37.

Zemelak A. Ayele. (2017). EPRDF's 'menu of institutional manipulations' and the 2015 regional elections. Regional \& Federal Studies. 28(3), 275-300. 